\title{
SCHOOL MAPPING AND GEOSPATIAL ANALYSIS OF THE SCHOOLS IN JASRA DEVELOPMENT BLOCK OF INDIA
}

\author{
S. Agrawal ${ }^{\mathrm{a} *}$, R. D. Gupta ${ }^{\mathrm{b}, \mathrm{a}}$ \\ ${ }^{a}$ GIS Cell, Motilal Nehru National Institute of Technology, Allahabad -211004, U.P., India - sonam@mnnit.ac.in \\ ${ }^{\mathrm{b}}$ Civil Engineering Department, Motilal Nehru National Institute of Technology, Allahabad -211004, U.P., India - \\ gupta.rdg@gmail.com
}

Commission II, WG II/3

KEY WORDS: School Mapping, Catchment, GIS, Thiessen Polygon

\begin{abstract}
:
GIS is a collection of tools and techniques that works on the geospatial data and is used in the analysis and decision making. Education is an inherent part of any civil society. Proper educational facilities generate the high quality human resource for any nation. Therefore, government needs an efficient system that can help in analysing the current state of education and its progress. Government also needs a system that can support in decision making and policy framing. GIS can serve the mentioned requirements not only for government but also for the general public. In order to meet the standards of human development, it is necessary for the government and decision makers to have a close watch on the existing education policy and its implementation condition. School mapping plays an important role in this aspect. School mapping consists of building the geospatial database of schools that supports in the infrastructure development, policy analysis and decision making. The present research work is an attempt for supporting Right to Education (RTE) and Sarv Sikha Abhiyaan (SSA) programmes run by Government of India through the use of GIS. School mapping of the study area is performed which is followed by the geospatial analysis. This research work will help in assessing the present status of educational infrastructure in Jasra block of Allahabad district, India.
\end{abstract}

\section{INTRODUCTION}

Education is an inherent part of any civil society. Proper education facilities generate the high quality human resource for any nation. Therefore, government needs an efficient system that can help it in analysing the current state of education and its progress. It also needs a system that can support in decision making and policy framing. Geographic Information System (GIS) can serve the mentioned requirements not only for government but also for the general public.

GIS is a collection of tools and techniques that works on the geospatial data and is used in the analysis and decision making. GIS is required for very diverse fields from government to common public, from commercial to social service, from science to defence. According to Bolstad (2012), GIS is "a computer-based system to aid in the collection, maintenance, storage, analysis, output, and distribution of spatial data and information" whereas Burrough (1986) defined GIS as "a powerful set of tools for storing and retrieving at will, transforming and displaying spatial data from the real world for a particular set of purposes". GIS is a system that works on the spatial as well as attribute data.

Today location component of the data become very important. It is estimated that the eighty percent of the data contains spatial aspect (Klinkenberg, 2003). During the recent past, availability of location data have increased exponentially due to the growth in the field of remote sensing, Global Positioning System (GPS), GPS enabled smart devices, etc. This has resulted in the increase of the demand of GIS and web GIS. Now most of the people, facilities and phenomena can be reference by the location (Openshaw and Abrahart, 2000).
This research work is an attempt to support Right to Education (RTE) and Sarv Sikha Abhiyaan (SSA) program that runs under the Government of India. The Right of Children to Free and Compulsory Education (RTE) Act, 2009, was added in Indian constitution that provide the right of education to a child with the obligation on the government to ensure admission, attendance and completion of elementary education of the child (Ministry of Human Resource Development, 2016). Various norms for the schools regarding the teachers, infrastructure, curriculum etc. have been given by this act. SSA is an education program started in the year 2000-01 with the aim of providing the universal access of education to the children. Such types of programs are the prerequisite for the implementation of RTE act. Implementation of this act will place a huge financial burden on the government (Mehrotra, 2012). Therefore, policy makers need an efficient system that can support them in the implementation of this act.

This research work required large amount of data. It was collected from different sources like Survey of India (SOI) topographical maps, GPS data of school location and academic data. Various types of maps were generated using GIS, which gives better visualization of education related data. It helps the decision makers in indentifying the hotspots.

In order to meet the standards of human development, it is necessary for the government and decision makers to have a close watch on the existing education policy and its implementation condition. This research work will help in assessing the success of any policy. In case of any discrepancies, it will help in identifying the problem areas and 
can also support in finding the remedial solutions of the problems.

\section{STUDY AREA}

The Uttar Pradesh is located in the northern part of India. It is divided into 75 districts. Allahabad is one of the important districts known for its educational and religious significance. According to the administrative division, Allahabad district is divided into eight tehsils. Tehsils are further divided into twenty community development blocks. Blocks are then divided into villages. Bara tehsil is divided into Jasra and Shankargarh blocks. Jasra block is the study area of this research work. The study area lies between $25^{\circ} 07^{\prime} 20^{\prime \prime} \mathrm{N}$ to $25^{\circ} 21^{\prime} 28^{\prime \prime} \mathrm{N}$ latitudes and $81^{\circ} 38^{\prime} 06^{\prime} \mathrm{E}$ to $81^{\circ} 50^{\prime} 27^{\prime \prime} \mathrm{E}$ longitudes. It covers $265.38 \mathrm{~km}^{2}$ area having the total population of $1,77,185$ as per $2011 \mathrm{Census}$ of India. There are 114 villages in Jasra block.

\section{SCHOOL MAPPING}

Type School mapping is an important part of web GIS in education sector. According to (Al-hanbali et al., 2005), "School mapping is the art and science of building geospatial databases with relational databases of educational, demographic, social and economic information for schools and educational directorates to support educational planners and decision makers." Hence web GIS works as the visualization tool and also help in planning and decision making. It could be used in the infrastructure development and upgradation of schools by combining several indicators (Attfield et al., 2002). It provides the tools and techniques that handle the education from geographic perspective (Mendelsohn, 1996). Many times, it helps the officials when they require support for making the decisions like:

- Is there a requirement of new school?

- What should be the location of new school?

- Is there proper space for each student in the existing school?

- In making what-if analysis?

In literature, some examples of school mapping can be found. In the paper (Hite, 2008), discussed about the concept and development of school mapping. A case study can be found in the paper (Galabawa et al., 2002), that discussed the impact of school mapping in Tanzania and studied its after effects on the education. Another work on school mapping was carried out in Indian context that help the decision maker in identifying the new school locations (Govinda, 1999). Another paper (Odhiambo and Imwati, 2014), have shown the used GIS for education in the Kenya.

\section{DATA COLLECTION}

In the present work, 204 schools have been taken for the school mapping which are operational in 114 villages of Jasra block. Following steps were taken for the collection of data.

\subsection{Village Boundary Map}

Village map of Jasra block has been taken from National Information Center (NIC), Government of India. It is used for the extraction of village boundary map through georeferencing and on-screen digitization. Total 114 village boundaries have been digitized. An attribute table was built that consist of village name, code etc. The census data was also added in this table that provide total population, gender wise population, number of literate, etc.

\subsection{GPS field survey}

The location of each school of Jasra block has been collected using the hand held GPS. Trimble Juno 3B handheld GPS with 2-5 meter real time accuracy has been used for this purpose. There are 204 schools in Jasra block. Field survey using GPS has been done to collect the location of all these schools. This data was later downloaded on the computer and then converted into the point shapefile.

\subsection{Attribute Data Collection}

Education data like number of schools, student enrolment, gender and caste wise enrolment, number of teachers, examination results of previous academic session, classrooms condition, repair needs, etc. have been collected from District Information System for Education (DISE), New Delhi, India. This data served as the attribute data in the geographic database. DISE is a school-based annual information system that provides data on important aspects of a school. It covers all recognized, unrecognized, government and private schools. National University of Educational Planning and Administration (NUEPA), New Delhi publishes the school related data which is received from the states.

\section{GEOSPTAIAL ANALYSIS OF DATA}

The geospatial analysis on the collected data has been performed in this research work under GIS environment. The school position data collected by the GPS is converted into the point shapefile. The village boundary is shown as the polygon shapefile. The analysis has been performed on the basis of attribute data collected from the DISE. Various spatial utility maps have been created for this purpose. The results of the analysis are shown in the form of maps. For these maps datum is WGS 84 and projection system is UTM Zone $44 \mathrm{~N}$.

\subsection{Literacy Map}

Figure 1 shows the literacy map of the Jasra block. It is generated with the help of Census, 2011 of India (Census of India, 2011) that provides the population as well as male and female literacy data. Different colours are used to show the literacy rate in the villages. It can be concluded from the map that in most of the villages, literacy rate is less $65 \%$. The areas with black and red colour which includes 16 villages, are of the major concern because at these villages more than half of the total population is illiterate. Out of 114 only 20 villages have more than $65 \%$ of literate population. This map also contains the pie chart that shows the male literacy by yellow colour while female literacy by green colour. It can be observed that in most of the villages male literacy is much higher than the female literacy. At no place female literacy is more than the male literacy, except at 6 villages where both are equal. This map helps in locating the hotspots where there is an urgent need to promote education. Also more efforts are required for the encouragement of female literacy as it is significantly lower than the male literacy in most of the villages.

\subsection{School Location Map}

Figure 2 is showing the position of schools that are collected through GPS based field survey. The data collected through GPS is exported to point shapefile where each point in the map is the location of the school listed in DISE data. Each school is labelled by its name. 


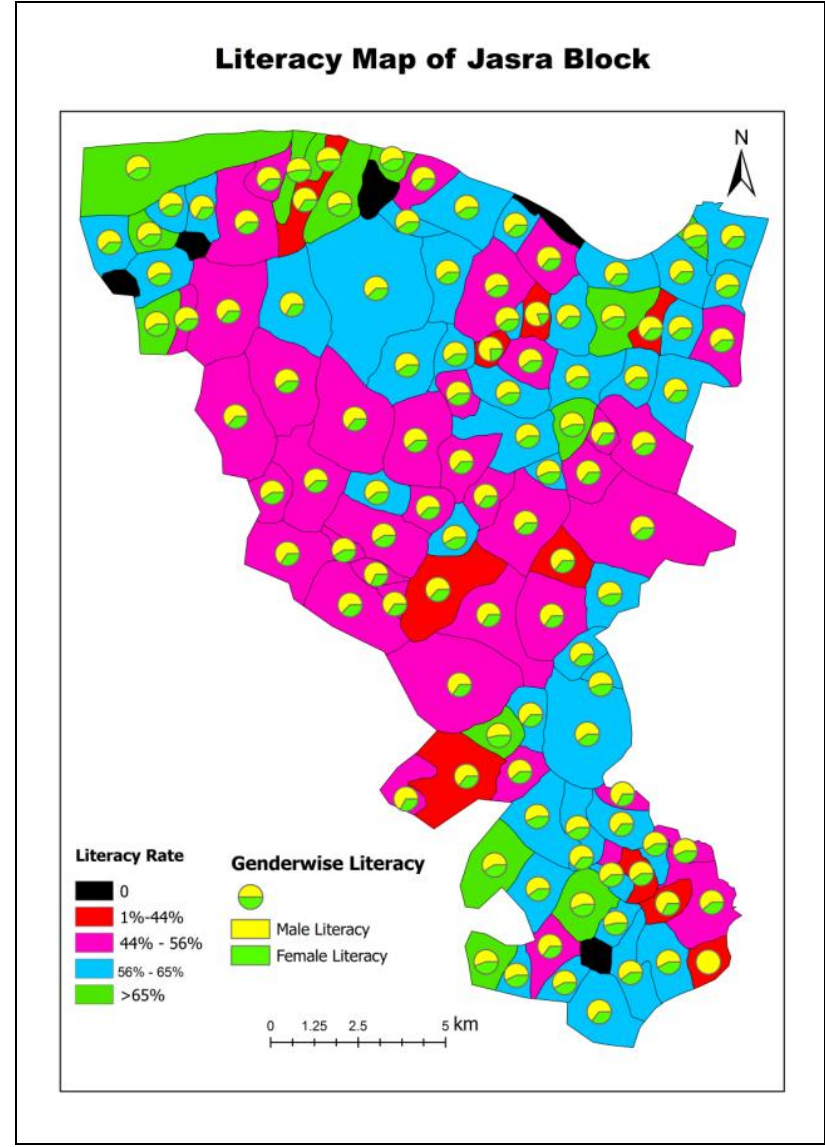

Figure 1. Literacy map of Jasra block

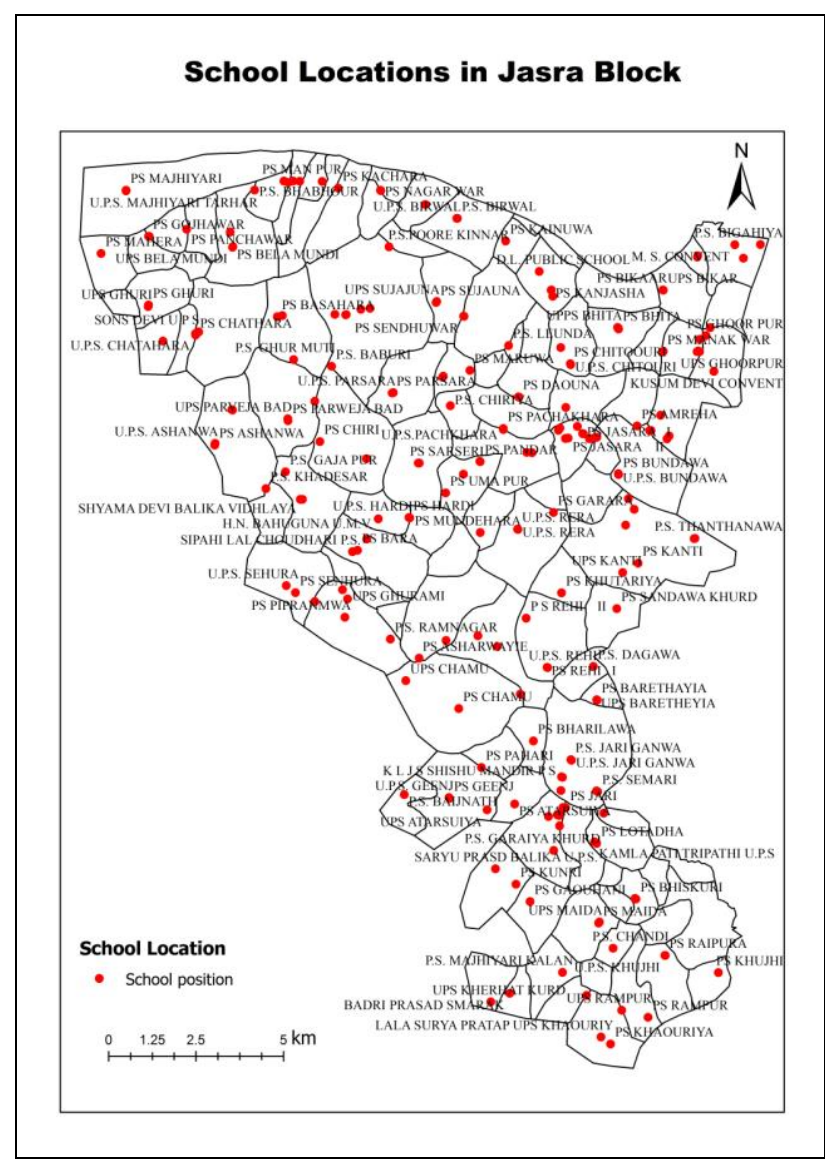

Figure 2. Location of schools collected by GPS survey

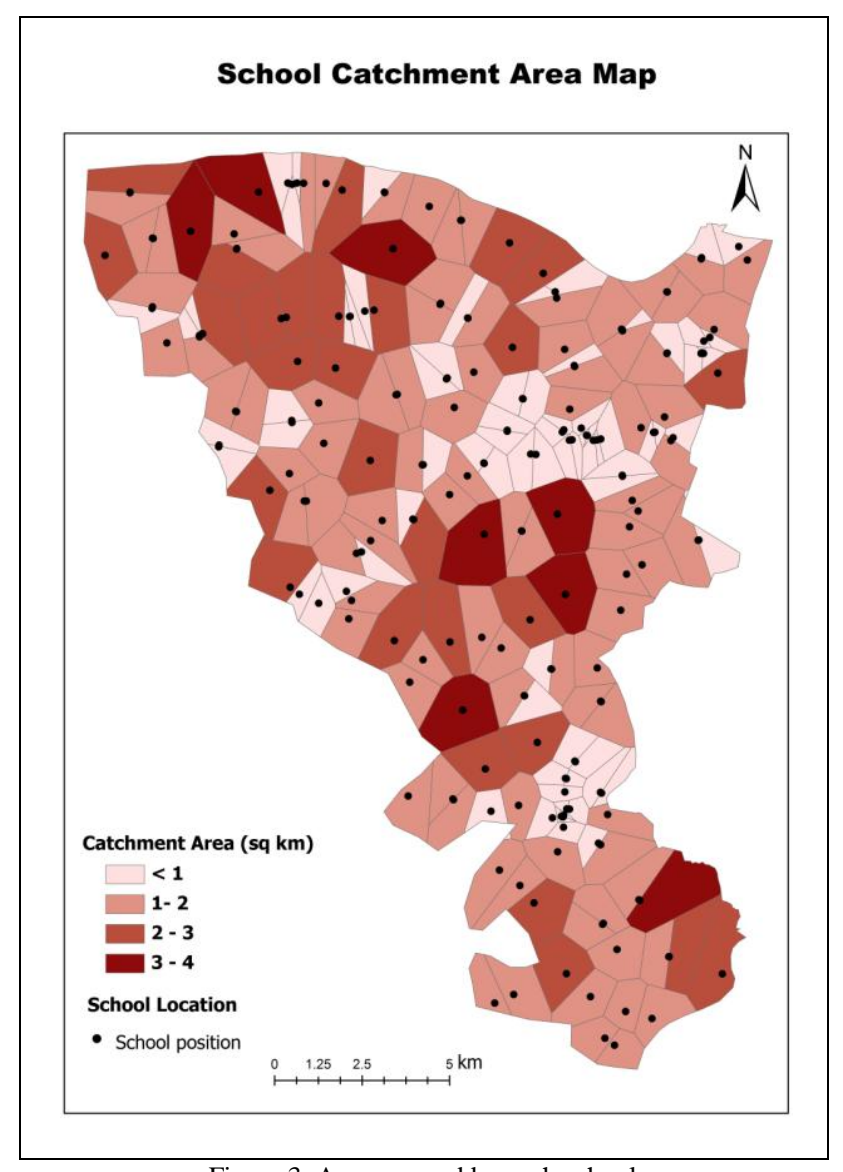

Figure 3. Area covered by each school

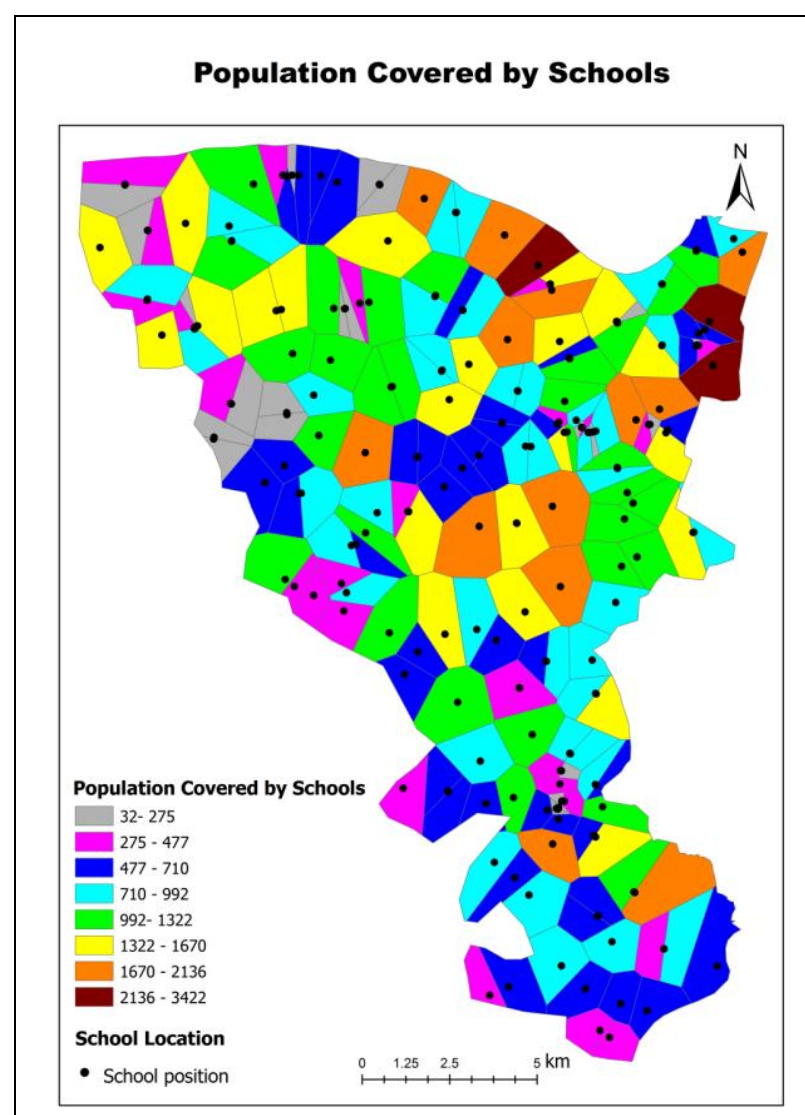

Figure 4. Population residing inside the school's catchment area 


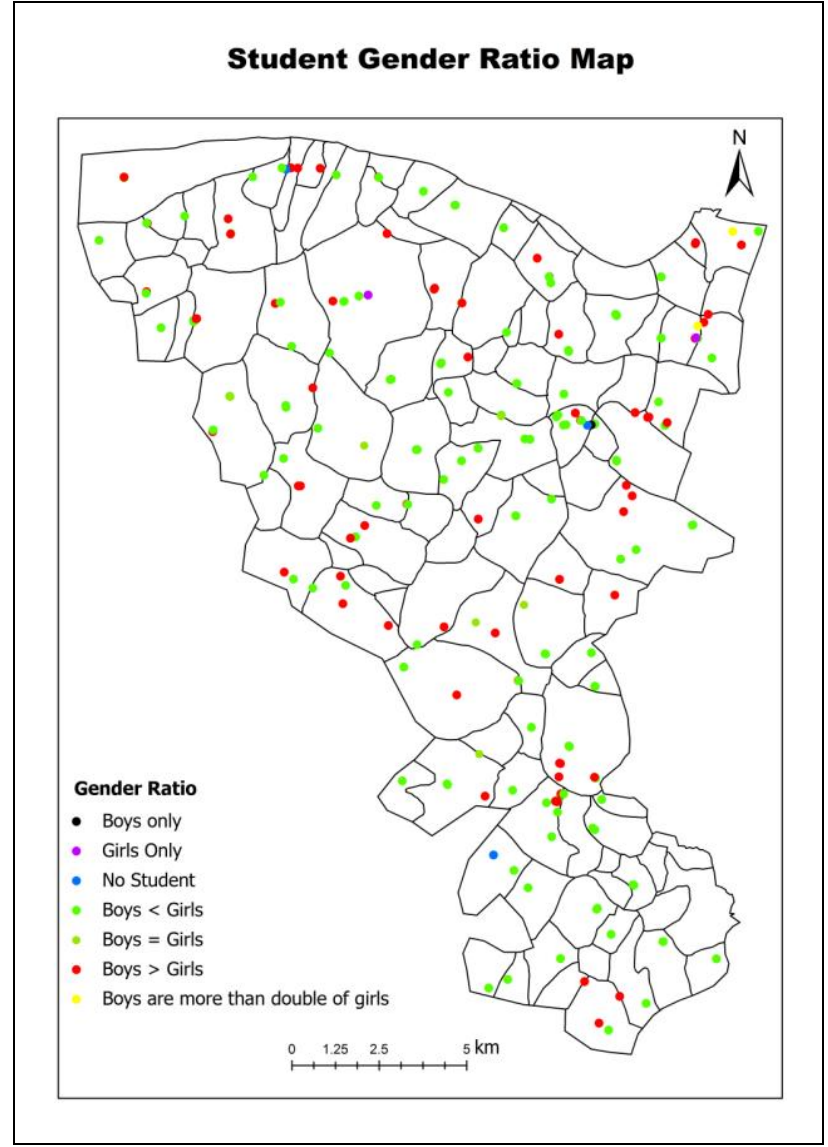

Figure 5. Boys and girls ratio in school

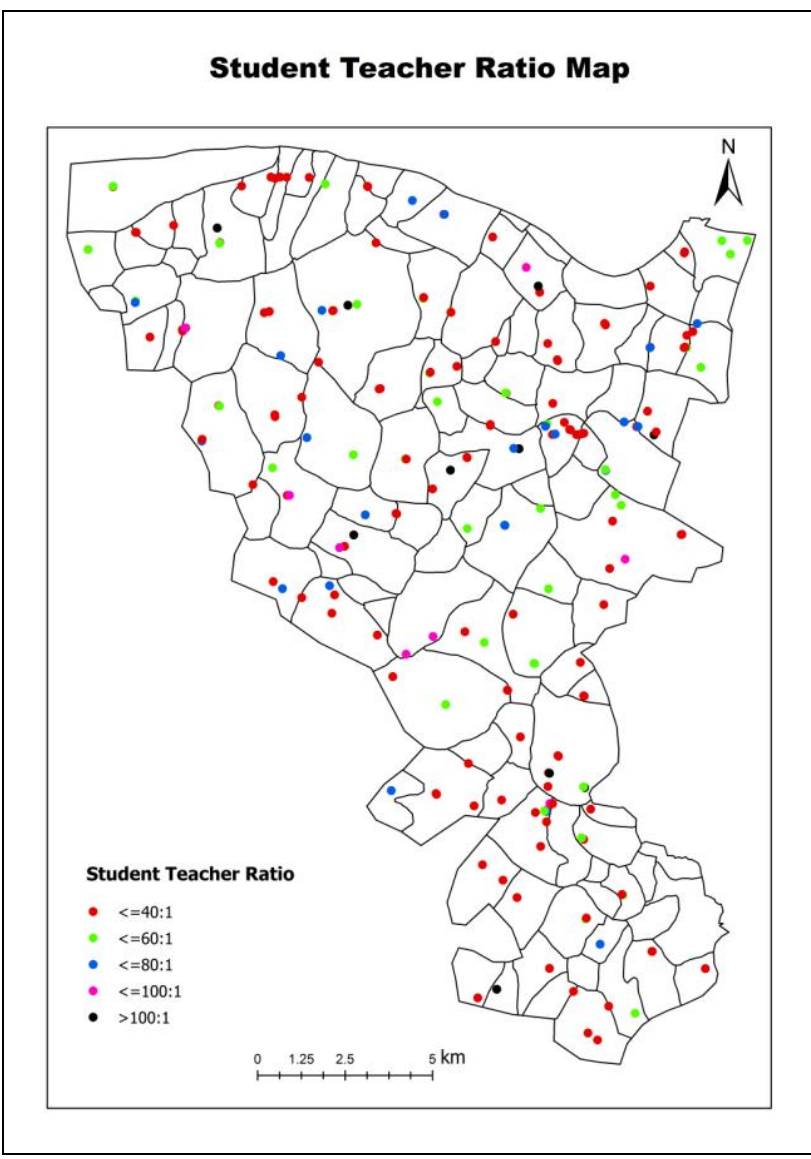

Figure 6. Student teacher ratio in school

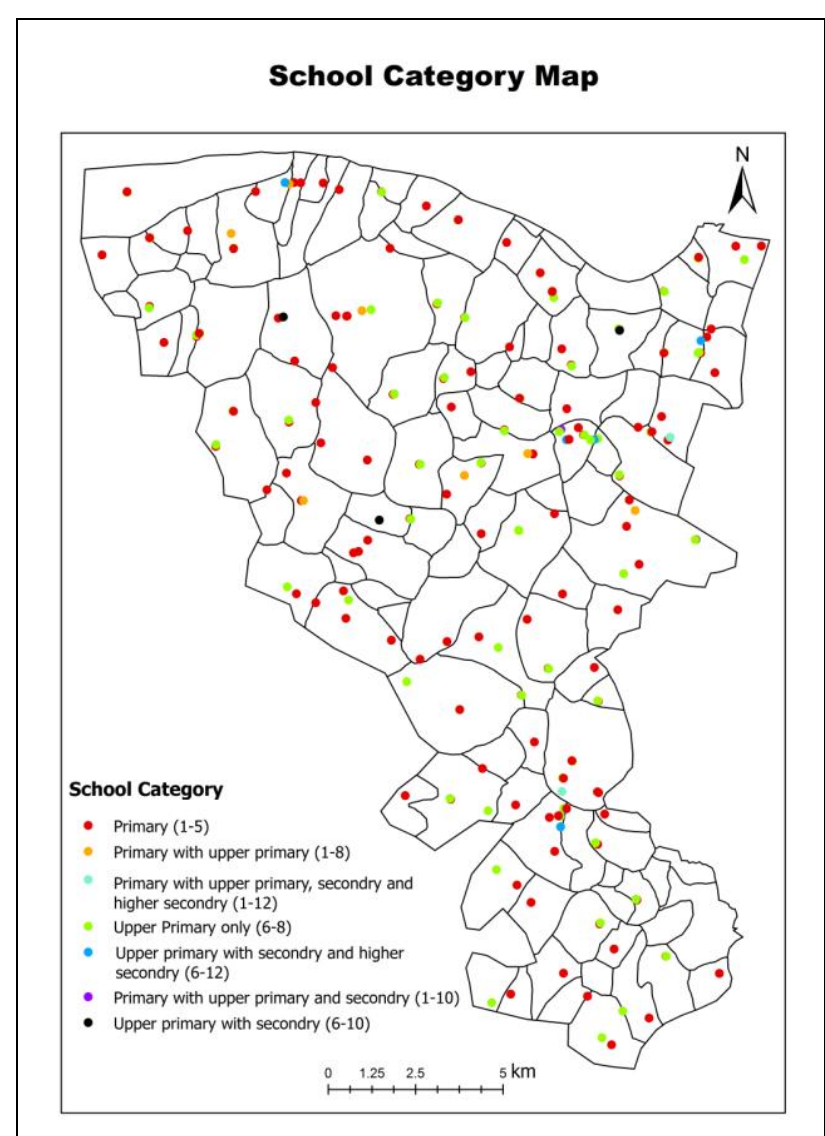

Figure 7. Map showing the category of each school assigned on the basis of class

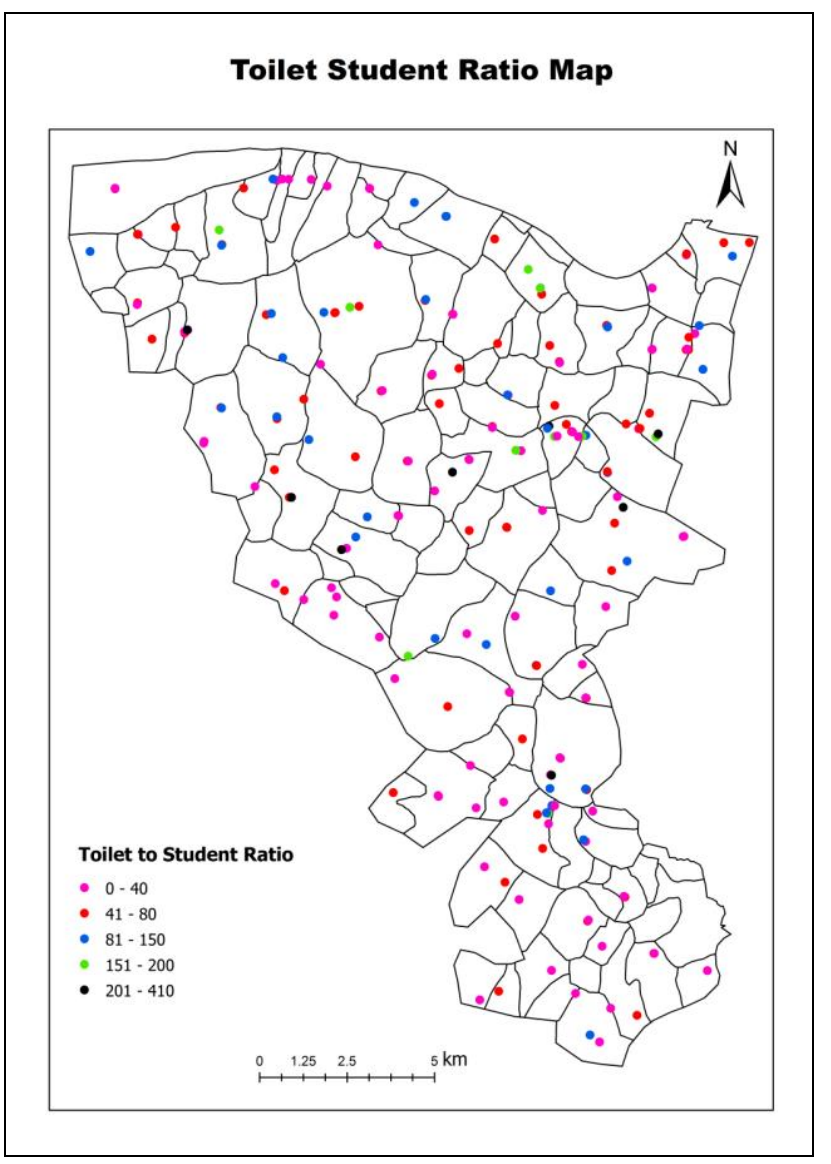

Figure 8. Map showing the toilet student ratio in school 


\subsection{School Catchment Map}

Figure 3 is showing the catchment area of each school. Here catchment area represents the influence area of the school means the population residing within this area will prefer the given school more than any other school. One of the method for generating the catchment area is by using the thiessen polygons (Fotheringham et al., 2001). Thiessen polygon is created on a set of points by joining the nearby points through lines and then drawing the perpendicular bisector of these lines. These bisectors join together and create the thiessen polygon (Brassel and Reif, 1979). It is a popular method used in many market analysis and meteorological studies like Derakhshan and Talebbeydokhti, 2011; Halls et al., 2001; Lewis, 2008 and Widaningrum, 2015. In the given map, for any location of the user, the nearest school can be easily identified by point in polygon analysis.

Large catchment area suggests the need of the new school at that place because it may has high population coverage and the child has to travel long distance to reach the school. For example in the given map, the area of the largest catchment is $3.659 \mathrm{sq}$. $\mathrm{km}$. which covers the population of 1571 people and the child living near the border will have to travel $1.84 \mathrm{~km}$. to reach the school. As per the State Government of the Jasra block, children in classes I-V need a school within $1 \mathrm{~km}$ while for those in classes VI-VIII requires a school within a distance of $3 \mathrm{~km}$ (Uttar Pradesh State Education Department, 2011).

\subsection{School Population Covered Map}

Figure 4 is showing the population covered by each school. It is calculated by multiplying the area of the thiessen polygon by the population density (Black et al., 2004). Population density is available at the village level from census data. Therefore it is required to identify the area of different villages that is covered by each thiessen polygon and then multiplying the area by the corresponding population density. Population covered is then computed by taking the sum of the previously obtained values. High population density in the catchment area of any school depicts the need of more schools in that area. The maximum population covered by a school is 3423 whose catchment area size is $2.10 \mathrm{sq} \mathrm{km}$. As per the State Government of the study area, for schools of classes I-V need to cover the population of at least 300 while for those of classes VI-VIII need to cater at least 800 population (Uttar Pradesh State Education Department, 2011). Thus this map helps in the identification of those schools whose population coverage beyond the government norms and the possible zones for the new schools.

\subsection{School Gender Ratio Map}

Figure 5 is showing the gender ratio of each school. Gender ratio is the number of girl students per thousand boy students. The schools where the boys are more than the girls can be discovered from the map. As the female literacy is lower than the male literacy in the study area, this map can help in identifying the schools where there is need to promote female literacy in order to reduce this imbalance. Out of 204 schools in Jasra block, 3 schools do not have any students, at 1 school there is only boys, at 2 schools there is only girls, at 125 schools boys are less than girls, at 6 schools boys and girls are equal and at 67 schools boys are more than girls. It can also be observed that at many schools the number of girls is more than that of boys, which reflects the changing mindset of the people towards the girl child education.

\subsection{School Student Teacher Ratio Map}

Figure 6 shows the student teacher ratio of each school. As per RTE, this ratio is ought to be $40: 1$ and $35: 1$ at primary and upper primary level respectively in every school. From the research investigations it is found that out of 204 schools, 123 schools are meeting this standard ratio which are shown by the red colour in the map. It is evident from the map that at many schools this ratio is not maintained. It can be used to identify the schools where there is a need to employ more teachers. The schools with pink and black colour are those where there is an urgent need of teachers as there is only one teacher on more than hundred students. There are 10 such schools where this ratio is more than 100:1.

\subsection{School Category Map}

Figure 7 is showing the category of each school which is given of the basis of the number of class. As per RTE, the school category is primary if it is only from class 1 to 5 , primary with upper primary for class 1 to 8, primary with upper primary and secondary and higher secondary for class 1 to 12 , upper primary only for class 6 to 8 , upper primary with secondary and higher secondary for class 6 to 12, primary with upper primary and secondary for class 1 to 10 , upper primary with secondary for class 6 to 10. From this map, it is evident that most of the schools are primary. Out of 204 schools in Jasra block, 124 are primary schools. Only 7 schools are up to class 12 .Thus, there is a need of more higher secondary schools.

\subsection{School Toilet Student Ratio Map}

There is a direct relation between the students and the basic facilities like water, toilets, electricity, etc. One such map is given in figure 8 , which shows the toilet student ratio of each school. As per RTE, this ratio is $40: 1$, i.e. there must be one toilet per forty students. Out of 204 schools, 123 schools are meeting this standard ratio which are shown by the pink colour in the map.. At 65 schools there is 1 toilet on 41 to 80 students, at 37 schools there is 1 toilet on 81 to 150 students, at 10 schools there is 1 toilet on 151 to 200 students and at 8 schools there is 1 toilet on more than 200 students. Thus there are many schools that urgent need to build more toilets as shown in the map.

\section{CONCLUSIONS}

GIS is creating the innovative ways for the analysts and decision makers to critically examine the diverse range of social and economic problems. The present paper illustrates how the GIS can be used in accessing the current state of education and also in locating the probable places of concern in the study area. The various analyses have been carried out on the mapped schools. The possible concerns have been raised along with each type of analysis. These issues need to be tackled for better education system. This paper provides the framework of the application of GIS in the education field, in particular, school mapping and their geospatial analysis required for the success of Right to Education (RTE) and Sarv Sikha Abhiyaan (SSA) programmes of Government of India.

\section{ACKNOWLEDGEMENTS}

The authors would like to thanks Mr. Dharamendra Kumar Meena for his field assistance in capturing the location of schools using hand held GPS, which is used in this study. 


\section{REFERENCES}

Al-hanbali, N., Al-kharouf, R. and Alzoubi, M. B., 2005. Integration of geo imagery and vector data into school mapping GIS data-model for educational decision support system in jordan. In: ISPRS, Commission II, WG II/5.

Attfield, I., Tamiru, M., Parolin, B. and De Grauwe, A., 2002. Improving Micro-Planning in Education through a Geographical Information System: Studies on Ethiopia and Palestine. School Mapping and Local-Level Planning. Paris, France.

Black, M., Ebener, S., Aguilar, P. N., Vidaurre, M. and El Morjani, Z., 2004. Using GIS to measure physical accessibility to health care. World Health Organization, pp. 1-22.

Bolstad, P., 2008. GIS Fundamentals: A First Text on Geographic, $3^{\text {rd }}$ ed., Eider Press, White Bear Lake, MN, USA.

Brassel, K. E. and Reif, D., 1979. A procedure to generate Thiessen polygons. Geographical Analysis, 11(3), pp. 289-303.

Burrough, P. A., 1986. Principles of geographical information systems for land resources assessment, Clarendon Press, Oxford.

Census of India, 2011. India, accessed 12 October 2015, $<$ http://censusindia.gov.in >

Derakhshan, H. and Talebbeydokhti, N., 2011. Rainfall disaggregation in non-recording gauge stations using space-time information system. Scientia Iranica, 18(5), pp.995-1001.

Fotheringham, A. S., Charlton, M. E., and Brunsdon, C., 2001. Spatial variations in school performance: a local analysis using geographically weighted regression. Geographical and Environmental Modelling, 5(1), pp. 43-66.

Galabawa, J.C., Agu, A.O. and Miyazawa, I., 2002. The impact of school mapping in the development of education in Tanzania: an assessment of the experiences of six districts. Evaluation and Program Planning, 25(1), pp.23-33.

Govinda, R., 1999. Reaching the unreached through participatory planning: School mapping in Lok Jumbish, India. UNESCO Publishing IIEP: Paris

Halls, P.J., Bulling, M., White, P.C., Garland, L. and Harris, S., 2001. Dirichlet neighbours: revisiting Dirichlet tessellation for neighbourhood analysis. Computers, Environment and Urban Systems, 25(1), pp.105-117.

Hite, S.J., 2008. School mapping and GIS in education microplanning. UNESCO Publishing IIEP: Paris

Internet-4: http://mhrd.gov.in/sites/upload_files/mhrd/files/ upload_document /Uttar_Pradesh_RTE.PDF (Accessed on $12^{\text {th }}$ March 2016)

Klinkenberg, B., 2003. The true cost of spatial data in Canada. Canadian Geographer, 47(1), pp. 37-49.

Ministry of Human Resource Development, 2016. Right to Education, India, accessed 10 April 2016, $<\mathrm{http}: / / \mathrm{mhrd}$.gov.in/rte>
Mehrotra, S., 2012. The cost and financing of the right to education in India: Can we fill the financing gap?. International Journal of Educational Development, 32, pp. 65-71.

Lewis, G.M., 2008. High value wind: a method to explore the relationship between wind speed and electricity locational marginal price. Renewable Energy, 33(8), pp.1843-1853.

Mendelsohn, J. M., 1996. Education planning and management and the use of geographic information system. UNESCO Publishing IIEP: Paris

Odhiambo, O.G. and Imwati, A.T., 2014. Use of GeoInformation Systems for Educational Services Provision and Planning in Asal Areas: A Case Study of Garissa CountyKenya. International Journal of Science and Research, 3(9), pp. 2432-2446.

Openshaw, S. and Abrahart, R.J., 2000. GeoComputation, Taylor \& Francis, London.

Uttar Pradesh State Education Department, 2011. The Uttar Pradesh right of children to free and compulsory education rules, India, accessed 01 April 2016, < http://righttoeducation.in /sites/default/files/Uttar\%20Pradesh\%20RTE\%20Rules\%2C\%2 02011.pdf\#overlay-context=>

Widaningrum, D.L., 2015. A GIS-Based Approach for Catchment Area Analysis of Convenience Store. Procedia Computer Science, 72, pp.511-518. 